\title{
IRISH FILM AND TELEVISION
}

\author{
THE YEAR IN REVIEW - 2020 \\ Roddy Flynn (ed.)
}

Copyright (c) 2021 by the authors. This text may be archived and redistributed both in electronic form and in hard copy, provided that the author and journal are properly cited and no fee is charged for access.

\section{Introduction}

Roddy Flynn

Reflections on the European Sports Film

The Racer (2020)

Seán Crosson

Sea Fever (Neasa Hardiman, 2019)

Jack Fennell

State of the Union: The New "Shooting Crew" Agreement

Denis Murphy

Wild Mountain Thyme and the Moral Panic around the Irish Accent on Film

Nicholas O'Riordan.

Vivarium (Lorcan Finnegan, 2020)

Emma Radley

"You Irish. You're fucking dark!"

Dead Still (RTÉ 2020)

Sheamus Sweeney

Rialto (2019)

Tony Tracy 


\title{
Introduction
}

\section{The Irish Audiovisual Sector in 2020: Living in the Shadow of Covid}

\author{
Roddy Flynn
}

Part of the appeal of cinema-going since its inception, especially with the emergence of purpose built picture palaces designed to appeal to more well-heeled patrons, has been the opportunity to seal oneself into a dark, womb-like environment and succumb the stimulation of the optical and auditory senses by high definition images and crystal clear sounds.

In an era of Covid-19, those positives have become major disincentives to cinemagoing. There have been no documented cases of Coronus Virus transmission occurring within an Irish cinema. Nonetheless, given the zombie movie-esque culture of fear, which has transformed our perception of strangers into potential vectors of transmission, how dedicated a cinephile would one need to be to contemplate entering a closed room shared with others even under socially-distanced conditions, with decent ventilation and mandatory maskwearing?

For much of 2020, personal inclination or otherwise in this regard was in any case moot. Under emergency conditions in Ireland, cinemas were required to shutter their doors for much of the year. The first lockdown saw cinemas close on March 25th and, even when they were permitted to re-open at the end of June, social distancing requirements severely curtailed their capacity. With the advent of a second wave in the Autumn, first Dublin (on 18 September) and then the rest of the country (October 5) moved to Level 3 restrictions which saw all cultural venues shut again. They would re-open briefly for the month of December but as it became evident that a third wave was sweeping over the country the introduction of Level 5 restrictions saw the shutters of cinemas close again and, at time of writing (March 2021), their doors remain shut. In all, in the twelve months from March 2020 to March 2021, Irish cinemas were only able to operate for a third of that period. Even when open, social distancing restrictions -1 or 2 metres spaces between individual cinema-goers and a cap of 50 people in any auditorium - severely curtailed the numbers who could attend.

Detailed figures on how this has affected Irish cinemas are, unsurprisingly, not available. (Medialive.ie, usually our go-to source for such data simply stopped publishing monthly attendance figure after January 2020). Globally the impact has clearly been calamitous for the theatrical exhibition sector. Pre-Covid, global box or 2020 was predicted to be somewhere of the order of $\$ 44.5 \mathrm{bn}$. In fact, early figures from January 2021 suggest that it appears to have come in at scarcely one third of this. Given that Ireland has endured what is, by some distance, the longest lockdown in the EU (measured in terms of days of business closures) it's safe to assume that the impact on the local box office has been even more pronounced. Some sense of the likely decline in revenues is hinted at by estimates from Core Advertising which suggest that spend on cinema advertising in Ireland fell by $80 \%$ from $€ 7.6 \mathrm{~m}$ in 2019 to $€ 1.4 \mathrm{~m}$ in 2020 .

One consequence of this is that some of the films that might usually have formed the core of the annual review received either very limited big-screen releases or, in many cases, have seen those releases repeatedly and indefinitely delayed. Ireland's submission to the Academy of Motion Picture Arts and Sciences in the Best Foreign Language Oscar category, Arracht, $a$ famine-era drama written and directed by Tom Sullivan, was originally scheduled for an April $3^{\text {rd }} 2020$ Irish cinema release. However, the winner of best feature at the American Golden Picture International Film Festival in May 2020 has, as of March 2021, been unable to capitalize upon its generally positive critical reception with a theatrical release. Similarly, Herself, Phyllida Lloyd's film with Irish actress (and writer) Clare Dunne was 
positively reviewed in Variety and Screen Daily after it screened at Sundance in January 2020. However, lockdown closures persistently complicated a theatrical release in the UK and Ireland until, just before the Autumn 2020 lockdown kicked in, producers and distributors Element Pictures announced that the film's release would delayed until further notice. It also appears that the latest Desperate Optimists (Christine Molloy and Joe Lawlor) collaboration, Rose Plays Julie, a psychological thriller which premiered at the BFI London Film Festival in October 2019 and was due for a May 2020 Irish cinema release, has yet to reach the big screen. Similar fates befell The Winter Lake, Be Good or Be Gone, Redemption of a Rogue, and Boys from County Hell none of which appear to have received any kind of release at time of writing (early March 2021).

Of those that did go on release some pictures had the (mis?)fortune to do so just before the various lockdowns commenced. Nick Rowland's debut feature Calm With Horses, an Irish crime drama produced by Element Pictures opened on $13^{\text {th }}$ March, receiving scarcely a fortnight of cinema exposure at home. (It would subsequently become available to domestic audiences via Netflix in October 2020). Scottish director Peter Mackie Burns' big screen take on Mark O'Halloran's play Rialto (reviewed here by Tony Tracy) opened outside Dublin on Oct 2 and was due to open a week later in the capital in anticipation of a relaxation of the Level 3 lockdown that had been imposed on that county. In point of the fact the lockdown as instead extended to the country as a whole by October 18 and, in anticipation of this, the film moved online on October 9 (via platforms such as Barbican Home Cinema, Curzon Home Cinema, Volta and IFI@Home).

Vivarium, Sea Fever and Dating Amber flipped usual release patterns, receiving big screen releases during the summer in the 10-week window between the first and second lockdowns. However all three had already been made available online. Lorcan Finnegan's Vivarium (assessed by Emma Radley in this edition) which saw the director revisit the territory of his 2011 horror short Foxes in longform and with an internationally recognisable cast (Jesse Eisenberg and Imogen Poots) was due for a cinema release on March $27^{\text {th }}$ the very day on which the first stay-at-home order was issued. Some nimble footwork on the part of producer Fantastic Films mean that the film was available to stream from that date via a variety of platforms (iTunes / Apple TV, Amazon, Sky Store, Microsoft Store, PlayStation, Virgin, Google Play, Rakuten, BT, Curzon Home Cinema and the BFI Player). The Neasa Hardiman-helmed horror thriller Sea Fever - another Fantastic Films' production - also saw its initial theatrical release date (April 10) transmogrified into a April 20 Video-On-Demand debut via Wildcard Distribution while David Freyne's Dating Amber a 1990s-set coming-ofage drama, also debuted on a streaming platform, opening on Amazon Prime on June 4. (Jack Fennell reviews Sea Fever elsewhere in this year's edition).

Indeed, in effect, of the mainstream Irish productions due for release in 2020, only Broken Law and The Racer (released respectively in July and December) received anything close to "normal" releases. Indeed "mainstream" may be an inappropriate description from Paddy Slattery's energetic feature debut Broken Law given its reliance on crowd-funding but the acquisition of its Irish rights by Break Out Pictures (established in May 2019 by former Element Picture executives) ensured it received at least a limited cinema release. (Break Out also secured the Irish rights to Rialto and Arracht). Again, both films ended up on streaming platforms, Broken Law on Netflix from January 2021 and The Racer on Amazon Prime.

The enforced shift to online viewing presents a difficulty in assessing the wider impact of such titles. Although, as noted below, linear broadcasters such as the BBC and RTÉ routinely trumpet the success of their content on their on-demand platforms, streaming services have less incentive to do so, especially those operating a subscription model rather than a pay-per-view approach. Thus we have little clear sense of how many people actually watched Calm With Horses and Broken Law on Netflix and Dating Amber and The Racer on 
Amazon. (That we are living through an era when the opportunity for face-to-face watercooler promotion of such texts through word of mouth has been severely - if not entirely - curtailed by the transformation of normal work practices means we cannot glean even an informal sense of whether such texts are "circulating" extensively). In passing, however, it is worth acknowledging how fantasy genres - exemplified by Vivarium and Sea Fever - were, of their nature able to circumvent some of the difficulties faced by "straight" drama texts (i.e. their setting in pre-Covid conditions). Indeed, the arrival of Covid made both texts seem unusually prescient: Vivarium's depiction of a couple trapped in an isolated suburban housing estate clearly echoed the restrictive conditions that followed in the wake of then Taoiseach Leo Varadkar's mid-March 2020 "stay at home" plea. Similarly, many reviewers drew attention to the parallels between the manner in which the characters in Sea Fever were "infected" by the microscopic offspring of the aquatic monster encountered by a science research boat.

Even if the performance of individual texts on online platforms was veiled in mystery, the extent to which Covid conditions prompted a shift towards domestic consumption of screen content in 2020 was obvious. It may have gone largely unnoticed but the number of Irish households subscribing to Pay TV services had declined from $70 \%$ at the start of 2015 to $60 \%$ by January 2020. However, in the same period the number of active broadband subscriptions has grown from $1.706 \mathrm{~m}$ in 2015 to $1.763 \mathrm{~m}$ by the close of 2019 . This suggests that Irish consumers had already been engaging in a degree of "cord-cutting", cancelling subscriptions to cable and satellite packages and directly accessing content via broadband subscriptions (e.g. Streaming Video-On-Demand services, free and paid, Youtube, Torrent sites etc.). Research conducted by the Core Advertising Agency during the first lockdown suggested that Covid conditions significantly accelerated this shift, pointing to a dramatic upsurge in the use of both subscription and free on-demand services. $49 \%$ of Irish adults had access to Netflix at the start of 2020 but this rose to $63 \%$ by June. Core estimate that between 500,000 and 550,000 Irish households (or $31 \%$ of the total) had subscriptions by the middle of 2020. Other services - starting from a lower audience reach - made proportionately even greater gains. Disney Plus, which launched in Ireland on March 24 just after the first lockdown commenced, had reached $20 \%$ of all Irish adults by June. Amazon Prime and Apple TV both doubled their reach from $12 \%$ and $5 \%$ of adults to $26 \%$ and $10 \%$ respectively in the same period. The emphasis on fiction - comedy and drama - content within on-demand libraries suggests that audiences looked to streamers to escape the quotidian stress of living under lockdown conditions. Core's figures suggest more people were watching comedy on streaming services than any other genre.

In passing it might be noted that this growth in the popularity of such services also coincided with some public discussion of how at least some of the revenues they earn might by clawed back to the benefit of local audiovisual production. In 2019 the then Minister for Communications established a Future of Media Commission initially prompted by the need to address the persistent gaping holes in RTÉ's finances. Since expanded to consider all media sectors, the Commission spent 2020 receiving submissions from across the Irish media sector on how to maintain the viability of all media sectors in the face of collapsing advertising revenues for legacy (print and broadcast) media. In parallel a proposed Online Safety and Media Regulation Bill carried within it the promise of at least partially addressing this problem. The bill would transpose into Irish law Article 13 of the European Union Audiovisual Services Media directive require on-demand services to ensure that European works constituted at least $30 \%$ of their catalogues. However it also empowered member states to insist that such services financially contribute to the production of European works. Heads 76 and 77 of the bill, which is currently (March 2020) subject to pre-legislative scrutiny by an Irish parliamentary committee envisaged imposing a levy on audiovisual media services 
providers either based in Ireland or targeting Ireland from other EU member states).

If currently the vast bulk of that streamer content originated outside Ireland, the need for escapist entertainment was paralleled by a demand for local-relevant information allowing audiences to cope with the uncertainties prompted by Covid conditions. Unsurprisingly then, documentary and news were ranked second and third most watched genres accessed via ondemand services. This clearly rebounded to the benefit of platforms associated with linear broadcasters. Prior to Covid, the RTÉ player averaged 1 million streams per week. This doubled to 2 million over the course of the first fortnight in March and, while it dipped somewhat by mid-April, between January and June 2020, the RTÉ Player saw its overall use leap from $28 \%$ of all adults to $49 \%$ (a surge supported by the arrival of stand-out Irish audiovisual hit of the year Normal People on the RTÉ Player in May). Notably, Covid conditions appear to have prompted older households who might not previously have considered the RTÉ Player to reassess its utility. The Virgin Media Player also saw a 21\% year on year increase in usage between March and May 2020 with documentary series The Guards: Inside The $K$ emerging as the single most popular show on the Player in that period.

Although consumption of media texts within the confines of the private sphere is hardly novel, the wholesale shift towards an almost exclusive reliance on such modes of consumption is thought -provoking. Despite arrival of radio and television broadcasting in the $20^{\text {th }}$ century addressing domestic (and implicitly family) audiences within their hermetically sealed living units, for most of the $20^{\text {th }}$ century, cinema remained a genuine mass medium consumed in the co-presence of potentially thousands of others viewers. The main site of consumption for notionally large-screen texts may have shifted to the small screen in the last quarter of the $20^{\text {th }}$ century. Nonetheless, if cinemas retained a key role as an initial launch platform for films and also a status as the "best" place to watch films, this seems to have been particularly true for Ireland. Even if attendance levels in have declined since 2017, 15.1m tickets were still sold in 2019 and Ireland's 3.3 visits per capita in that year was the highest in Europe. If watching films remained at least in part a public experience, it was often one beset by the tension of having to accept the vagaries of how other members of the audience behaved. Film screenings are sites of negotiations with strangers, where we simultaneously tolerate the sounds (and odours) of popcorn and nachos being consumed, phones being answered and scarcely muted expositions of onscreen events while we ourselves engage in agonisingly long drawn out attempt to unwrap a sweet in as close to total silence as possible. But they are also spaces where we learn about how others see the world as we encounter a variety of audience responses to the same onscreen events. Witness how different sections of an audience for a comedy disagree on what is funny with laughter emerging at different moments from different regions of the auditorium. The advent of home cinema systems (average sizes of LCD sets doubled from 23 inches to 47 inches in the US between 1998 and 2018) may promise a theatrical experience in your living room but this emulates the audiovisual experience rather than the social one. Pandemic conditions inevitably encourage us to regard strangers as a source of a new kind of - passive, unintended - threat. The related disappearance of spaces for social connection, necessarily intensify the atomisation of social life, curtailing our scope for empathy at a point when debates about how to live with/against Covid 19 require such fellow feeling more than ever. This raises the question of how existing media forms such as cinema might be instrumentalised to address these social lacunae, especially if pandemic conditions persist indefinitely.

Inevitably, of course, the screen texts that were available to audiences in 2020 could not have anticipated the impact of Covid-19 and the sense of displaced reality that characterised the experience of watching narratives set in "normal" conditions in the midst of a Covid reality that seemed at times to be drawn from fiction. (Notably Steven Soderbergh's 2011 medical thriller Contagion enjoyed a wholly unpredictable new lease of life on Netflix). 
This was not merely the case with regard to the filmic texts mentioned above but also those overtly designed for the small(er) domestic screen. If the February debut of the second series of Virgin Media's Blood meant that the Adrian Dunbar-starrer was largely able to evade the pandemic context the same was not true of Virgin Media's other major contribution to local drama, The Deceived, a psychological thriller from Derry Girls creator Lisa McGee (with her husband Tobias Beer) which aired in September 2020. Despite this and doubtless buoyed by the presence of Paul Mescal (of whom more in a moment), the low-key series performed well across Virgin's linear and on-demand platforms, its 114,000 average audience placing it within touching distance of soap stalwart Emmerdale's viewing figures.

For its part, though still reliant on finding overseas co-production partners as a prerequisite for greenlighting new work, RTÉ was fortunate to find its fiction cupboard relatively replete with Irish-facing comedy given audience preferences under pandemic conditions. Season Three of the BBC co-produced The Young Offenders was the most popular comedy or drama on Irish television screens across the summer months while the October slot offered to Season Two of the Amy Huberman-penned sitcom Finding Joy (produced with support from US Streamer Acorn TV) maintained the high standard of scripting and performance (though apparently not the audiences) established in the first series. Perhaps more surprisingly The South-Westerlies, a six-part comedy-drama set in a coastal town in Cork about to welcome a Norwegian-owned wind farm, performed well with Irish audiences in Autumn 2020, securing average audiences of around 260,000 views in its Sunday evening slot. This occurred despite an, at best, lukewarm local critical response to characterisation that seemed anxious to at least nod in the direction of the kind of soft primitivism associated with texts like The Quiet Man. That the series also involved finance from Acorn TV at least raises questions as to the extent to which trans-Atlantic funding shaped such representation. (One (US) review described the show - approvingly - as an "Irish version of a Hallmark movie"). Yet another Acorn coproduction, the comedy drama Dead Still, could hardly have been further removed from such tropes. Broadcast in November and December, the series was set in the macabre world of a Victorian Dublin photography studio specializing in memorialising the recently deceased and, as Sheamus Sweeney notes in his review, offered a vision of Dublin rarely seen on our screens: as a city at once part of the British Empire but also culturally removed from that imperial core.

Ironically, what unquestionably became THE Irish-themed screen event of the year Element Pictures' adaptation of Sally Rooney's novel Normal People - was made without financial support from any Irish broadcaster. The success of Rooney's first novel Conversation With Friends in 2017 had prompted interest in screen rights for Normal People as early as Spring 2018 while it was still in galley stages. Element Pictures' pursuit of the rights was underwritten by an advance commitment from the BBC's Head of Drama to greenlight its actual production. The acquisition proved to be a sound investment as the novel became something of a transatlantic literary fiction publishing phenomenon immediately after its August 2018 release. Girls creator Lena Dunham tweeted that Rooney was her favourite writer working in modern fiction a sentiment echoed months later by influencer/model Emily Ratajkowski. That both endorsements came from two figures noted for their public embrace of sex-positive attitudes may offer some insight into the wider public embrace of the novel.

As a novel, Normal People's appeal owed much to Rooney's spare writing style, and her excavation of the interior lives of her two intense protagonists. At one level the book is arguably somewhat conservative: Marianne is the princess, trapped in a (mainly figurative) castle by her wicked (not step-)mother and brother who is ultimately "saved" by the proletarian Connell. ("No one is ever going to hurt you like that again"). But the book is far more than an updated fairy tale, illuminating as it does the millennial condition. While meeting classical markers of masculinity (sporting prowess, physically attractive to the 
opposite sex) Connell is also haunted by demons born of his having to negotiate social caste as his intellectual prowess powers him upwards through the glass ceiling of academe. Notionally better-resourced (at least financially) Marianne turns out to be the victim of longterm physical and psychological abuse which, it is clearly implied, has shaped her submissive sexual identity. That she encounters a sequence of male characters (other than Connell) only too willing to exploit this seems to reflect ubiquity and influence of pornography for those born in the era of broadband and smartphones. If the novel acknowledges a crisis of masculinity through Connell it also emphasises that patriarchal structures of dominance (sexual or otherwise) very much remain operative and pervasive.

This is sensitive territory, especially in the wake of \#MeToo and \#WakingTheFeminists consciousness-raising efforts and must have given the producers food for thought in crewing the production. The use of not one but two female Directors of Photography (Suzie Lavelle and Kate McCullagh) is notable simply because of the historic dominance of men in that role. Production Designer Lucy Van Lonkhuyzen's realisation of Irene O'Brien's art direction received extensive praise and even the Stunt Coordination was overseen by veteran Eimear O'Grady. There is, incidentally, nothing remotely tokenistic about any of these hires: all five have come up through the post-1993 expansion of screen production activity on this island. Nonetheless, that so many roles were filled by women is notable. Alice Birch collaborated with Sally Rooney on the screenplay and though Mark O'Rowe also worked on the series his input was limited to final episode. Given Element's involvement and the setting of the novel, Lenny Abrahamson's attachment as a director for the first six of the twelve episodes had an air of inevitability about it. But Abrahamson's first four features were squarely focused on studies of contemporary masculinity even if Room emphasis on Brie Larson's performance as "Ma" demonstrated that Abrahamson's comfort with a female perspective. Thus the decision to bring Hettie McDaniel in to helm the second half of the series seems calculated to ensure that a female gaze co-anchored the series. Though possibly best known for directing Blink in 207, widely regarded as the best single episode of the post-2005 revival of Doctor Who, MacDonald also had some form in exploring teenage sexuality going back as far as her 1996 feature debut "Beautiful Thing" (another study of an initially hidden relationship).

The success of the resulting series was simply remarkable. There were 21.8 million requests for the first episode in the week after it appeared on the BBC iPlayer, doubling the record established by Killing Eve in 2018. (By November 2020 this had grown to over 60 million requests). In Ireland, the series also set a new record on the RTÉ Player with 3.3 million streams by June 2020, far outstripping the 1.2 million stream record for Love/Hate Season 4 in 2013. This translated into huge international interest in the series: the involvement of the Disney-owned US video-on-demand platform Hulu in funding the series (along with support from Screen Ireland and Section 481 funding) ensured that it would find an American audience from the outset. However, by May 2020, rights to the series had also been sold in Australia, Canada, Denmark, Greece, Iceland, Finland, New Zealand, Norway, Russia, Sweden, Germany, Austria, Switzerland, France, Italy, Spain, Benelux, Latin America, and Japan. The series also received two Golden Globe and four Emmy nominations. Never has an Irish-set series have received so much exposure.

To what extent pandemic conditions contributed to this success is debatable. Abrahamson has speculated that lockdown viewing conditions certainly helped, implying that the sense of been sealed inside one's home conditioned viewers to embrace the intimacy of the Marianne/Connell relationship. That that intimacy included some element of overtly sexual content prompted some surprisingly reactionary public "debate" in Ireland with complaints about primetime pornography. The screen version certainly includes some scenes which Rooney allowed to occur off the page in the novel but the sensitive manner in which 
the sex scenes were handled (overseen by Intimacy Coordinator Ita O'Brien) suggests that only those who consider displays of genitalia to be ipso facto pornographic could have found Normal People even remotely problematic in this regard. (Indeed, in a subtle divergence from the novel, the depiction of Marianne's BDSM relationship later in the series raises the possibility that the character has more agency in determining the nature of that relationship than the novel suggests).

The success of Normal People engendered calls for a sequel, though Rooney has, as yet, announced no plans for a follow-up novel. Some sense of the BBC's anticipation that the project would be a success can be gleaned from the fact that in March, even before Normal People had aired, the station commissioned the same creative team - Element, Alice Birch and Abrahamson - to begin work on an adaptation of Rooney's first novel Conversations with Friends which at least inhabits the a similar milieu.

The question was whether Covid conditions would actually permit anything to be actually shot. Virtually all live action production activity - from Ridley Scott's medieval blockbuster The Last Duel to the smallest micro-budget work - ceased in March. (The shuttering of the former saw actor Matt Damon become a familiar figure around the streets of south Dublin suburb Dalkey as he and his family waited out the first lockdown). A survey published by Screen Producers Ireland in June 2020 suggested that a total of 24 productions ceased operations while a further 59 companies had had to delay the start of production.

Against this, the screen production sector that was able to pivot quickest to adjust to lockdown had also become the single biggest element of the industry according to figures published by Screen Ireland in May 2020. From accounting for $20 \%$ of all production expenditure in Ireland in 2014, the Irish animation sector accounted for 50\% (equivalent to film and television combined) in 2019 and employed just over 2,000 people by mid-2020. This growth had been reflected in the expansion of Animation Ireland, the trade association for Ireland's animation studios, membership of which grew from 14 studios in 2015 to 33 by 2020. More animation projects - 39 in all - received Section 481 relief in 2019 than any other screen form. The nature of the animation production process meant distance working was - at least compared with live action - relatively straightforward to adjust to and the industry as a whole found itself sequestered before high-end desktops in spare rooms and attics across the country. Although these are clearly still less than ideal circumstance, production has continued more or less unabated. Indeed at a consumption level, Cartoon Saloon's Wolfwalkers (produced for Apple) was the most successful local cinema release in 2020, going straight to No.1 at the Irish box office after its release on December 4).

With regard to the live action shutdown, Screen Ireland were quick to respond, announcing the first of a sequence of measures to shore up the industry on March 19 2020. In general Screen Ireland adopted the perspective that funding should be refocused away from production activity (where at least temporarily it couldn't be actually spent) and aimed more at the development process, thus both maintaining some cash flow into production companies and ensuring that whenever production was allowed to recommence that the industry as a whole would be ready to spring back into action.

The initial measures saw Screen Ireland commit to providing $90 \%$ funding upfront on all development loans to Irish screenwriters and production companies through to $31^{\text {st }}$ May 2020, while a blanket extension was made to all existing development and production loan offers due to expire. For those productions that had been completed before the first lockdown kicked in (The Racer, reviewed here by Sean Crosson, was fortunate to wrap on February 28), additional marketing and distribution support was promised while Screen Skills Ireland promised not only to continue delivering training online but also to do so free-of-charge.

As it became clear that lockdown conditions would be in place for months rather than weeks, these measures were enhanced. On April 17 Screen Ireland announced that the value 
of the Strategic Slate Development Fund would be increased from $€ 1$ million to $€ 3$ million and that a further $€ 1$ million in Enhanced Development Support would be made available to Irish production companies working with writers on a project by project basis, (i.e. where the Strategic Slate Funding Scheme did not apply). Three other forward-looking schemes were initiated or expanded at the same time. The Creative Concept Development Scheme for Directors invested in "the early vision of a director to develop high value, well-refined projects" essentially facilitating directors in creating a proof of concept to bring to a producer or to the market. An additional $€ 100,000$ was added to the existing Screenplay Development and the Spotlight writing schemes, with the latter focused on mentoring early career writers. Finally Screen Ireland put $€ 150,000$ towards a Financial Planning Support fund to allow production companies to avail of professional advice from a financial consultant in drawing up financial plans to meet Covid conditions.

The publication of the Irish Government 'Economic Considerations for Reinstating Economic Activity' report at the end of May envisaged that the earliest live film production might recommence would be during Phase $3,\left(29^{\text {th }}\right.$ June $)$ of the Government's five stage plan. This would be subject to the provision of assurances from within the sector that practical issues (insurance, health and safety protocols and travel restrictions) had been addressed. By this stage the Screen Ireland Covid-19 Sub-Committee had already been working for some time with industry stakeholders - Animation Ireland, Screen Producers Ireland, Visual Effects Association Ireland, Commercials Producers Ireland, Screen Guilds of Ireland, SIPTU and Equity - to address these issues. Screen Producers Ireland was specifically tasked with drawing up health and safety production protocols which could be applied to the specific circumstances of individual productions. These were delivered in June and immediately accepted by the Department of Culture, Heritage, and the Gaeltacht as conforming to broader COVID-19 health and safety guidelines. These new Production Guidelines included information on options for modifying work structures to help to reduce contact, implementing sanitation regimes to reduce risk of transmission of COVID-19, and specific options for minimising risk in close contact activities such as costuming and make-up. Such protocols were not without cost implications however and, in recognition of this, Screen Ireland introduced a $€ 1$ million COVID-19 Production Fund to at least partially offset the additional costs making up to $€ 75,000$ available for individual productions.

Even after live action restarted under the new protocols, new state supports specifically targeting the sector continued to emerge. At the end of July, Minister for Media, Tourism, Arts, Culture, Sport and the Gaeltacht Catherine Martin T.D., announced a new $€ 10$ million pilot Performance and Production Support Package as part of a stimulus package for the economy as a whole. $€ 5$ millions of this was earmarked for the audiovisual sector with $€ 3$ million was dedicated to TV Drama funding. This followed on the appointment of former Virgin Media Television Head of Commissioning to the new role of TV Project Manager within Screen Ireland. This might have been interpreted as a short term attempt to cash in on the success of Normal People but in point of fact back in 2018 the Audiovisual Action Plan had identified a critical absence of funding for local drama production (not least due to the ongoing travails within RTÉ's finances). The TV Drama Fund was thus specifically designed to stimulate large-scale production activity across Irish TV drama and had already awarded $€ 900,000$ to five television drama projects by September 2020. In the same month Screen Ireland announced $€ 1$ million in funding for a joint development initiatives with RTÉ TG4 and Virgin Media. (Further clarity on how the fund would be used emerged in October when TG4 (in association with Screen Ireland) announced a call for applications to develop five (!) new 4-8 episode contemporary drama series targeting younger (under-35) audiences with up to $€ 50,000$ available per project). 
A final funding boost came with the October 13 announcement of the 2021 budget. Screen Ireland secured a funding increase of $€ 9$ million bringing the agency's capital budget to $€ 26.2$ million and the full budget (including administration) to $€ 30.09$ million for 2021 , the single greatest funding commitment to the agency since its revival in 1993.

In sum then, by the end of 2020, and notwithstanding Covid conditions, the Irish audiovisual sector was at least theoretically poised to rebound whenever "normal" conditions were restored. That the producers representative body, Screen Producers Ireland and the SIPTU Trade Union were able to sign off on a decade of negotiations to finalise an agreement covering work conditions and minimum pay rates for live-action film and TV productions (as explored by Denis Murphy in this edition) is clearly timely in this regard. Even with the early production shutdown, completed works supported by Screen Ireland amounted to 12 feature films, three television productions, eight animated TV shows, and 13 documentaries. In August Matt Damon returned to Ireland complete filming The Last Duel in Meath and Tipperary. October saw principal photography wrapped on Irish/Polish arthouse drama Wolf, the first independent film supported by Screen Ireland to shoot during the COVID-19 pandemic. In the same month, the Fintan Connolly-directed Barber (featuring Aidan Gillen as the eponymous detective working during a global pandemic) also completed shooting. The RTÉ commissioned - but, unusually BBC-developed - drama Smother from Irish novelist and screenwriter Kate O'Riordan had seen its Clare location shut down midway through a 12 week shoot which began in February. However, it was able to complete shooting during the summer and its March 2021 schedule date will see it reviewed in these pages next year. Another RTÉ drama commission, Kin, an Irish-set crime drama supported by Scandinavian streaming platform Viaplay commenced shooting in October 2020.

Furthermore, there is clearly an expectation that Ireland remains well-placed to exploit an ongoing demand for content from studios, broadcasters and platforms overseas. And there is a clear intent to develop production capacity within the state in anticipation of increased overseas-funded activity in Ireland. Addressing the Joint Parliamentary Committee on Media, Tourism, Arts, Culture, Sport and the Gaeltacht in December 2020, Screen Ireland Chief Executive Desiree Finnegan stressed the need to build on existing relationships with major studios and streamers. Weeks earlier Screen Ireland had advertised the position of a Los Angeles based Liaison to "support the Irish creative screen sector and strengthen US-Ireland relationships between the Irish screen industry and the US entertainment industry." Finnegan placed particular emphasis on how US funders of production had emphasized the need for more production infrastructure. For much of its existence, Ardmore Studios was not only the only studio space in Ireland but between its 1958 opening and the early 1990s, it often struggled to fill its sound stages. With the post 1993 expansion in production activity (and especially after 2010) more space was sought and as of 2020, Ardmore had been joined by the Ashford Studios setup at Ballyhenry in Co. Wicklow (which received planning permission in January 2019 to add a further four sound stages and 160,000 square feet of studio space to its existing three stage, 57,000 square foot offering) and the massive four stage 100,000 square foot Troy Complex in Limerick. (This doesn't even consider the Titanic Studios operation in Belfast). However, the Covid interregnum notwithstanding, anticipated demand from beyond Ireland's shores is such that even this level of studio provision is now considered inadequate. Thus in May 2020 - South Dublin County Councillors voted to selling a 48-acres site at the Grange Castle Business Park in West Dublin to Lens Media. Fronted by producer Alan Moloney and Windmill Lane founder James Morris Lens Media's planned "full-service media park" includes 12 sound stages alongside 100,000 sq. ft. of office space. Two months later Greystones Media Campus Limited applied for planning permission to develop a multistudio film and media campus located more or less midway between Ardmore and Ballyhenry consisting of 14 studios, offices, and ancillary production buildings. And there are at least two 
other studio proposals in the offing.

That overseas production will return to Ireland at an even greater level of activity when (if?) Covid conditions permit seems to be taken for granted. Similarly there is actual evidence to suggest the Audiovisual Action Plan strategy with regard to domestic - and especially television - production is actually being implemented, at least insofar as development spending is being deployed. How or whether work in the coming years will reflect the social and cultural impact of living through a pandemic remains to be seen.

Roddy Flynn is an Associate Professor at the School of Communications, Dublin City University. He is editor of the Annual Review and has authored Irish Media: A Critical History (2017) with John Horgan, and The Historical Dictionary of Irish Cinema (2019) with Tony Tracy.

roderick.flyn@dcu.ie

\section{Reflections on the European Sports Film The Racer (2020) ${ }^{1}$}

\section{Seán Crosson}

Sport cinema is not the first genre that one would associate with Irish fiction film (or any other European film culture for that matter) given the popularity of other genres, including melodrama, romantic comedy and the gangster genre in recent decades. However, while Hollywood has largely defined and popularised the genre, sport has featured prominently in the European context, including some notable Irish productions (Clash of the Ash (1987), The Boxer (1997), Studs (2006)). European sport cinema now includes both acclaimed works, from Rocco e i suoi fratelli (Rocco and His Brothers, 1960), This Sporting Life (1962), and Boxer a smrt' (The Boxer and Death, 1962), to distinctive national sub-genres such as Spanish 'Kick Flicks' (Ashton 2013). Furthermore, European Sport cinema has proven on occasion to be remarkably popular in specific contexts with indigenous productions breaking local box office records, including in Norway (Flåklypa Grand Prix (Pinchcliffe Grand Prix) (1975)), Russia (Движение вверх (Going Vertical (AKA Three Seconds) (2017)), and Spain (Campeones (Champions) (2018). As I have discussed previously (Crosson 2021), European sport cinema has historically been primarily national in both its focus and reception and in some contexts, as in Nazi Germany or Franco's Spain, this has involved the employment of sport on film to affirm and promote hegemonic and exclusionary constructions of national identity. However, the advent of the European Economic Community in 1957 (and the European Union (EU) in 1993) and the establishment of a range of European international coproduction and film funding initiatives - including Eurimages (established by the Council of Europe in 1989) and the EU's own MEDIA Programme (1991) - has encouraged and facilitated the increasing importance of coproduction partnerships in the production of European films, including sport cinema, accounting now for approximately $20 \%$ of relevant productions (Crosson, 2019). While more research is needed of these productions and the phenomenon more generally of European co-productions, this increasingly transnational production context does appear to be impacting upon the content of relevant productions with the narrower more nationalistic sentiments apparent in an early period less evident. In its 
place we find rather an increasing focus on international and inter-cultural concerns and encounters, including in some of the most commercially successful European sports films of recent years (e.g. Bend it It Like Beckham (UK/Germany/USA, 2002), Sixty Six (France/ UK, 2006), Looking for Eric (UK/ France/ Belgium/ Italy/ Spain, 2009), The Keeper (UK/ Germany, 2018).

This focus on the European context in discussing Kieron J. Walsh The Racer (2020) is necessary not just to place the production in relation to previous relevant sport cinema texts, but also because the film is above all defined and distinguished by its Europeanness. That it has an Irish director and co-producer (Blinder Films which has specialised in international coproductions) and is set in Ireland is secondary to this crucial aspect. This is already suggested from the early and unmissable Eurimages logo that fills the screen and precedes the film's title and the following logos for international entertainment company Caviar Films (with offices in Los Angeles, London, Brussels, Paris and Madrid), and French producer Jesus Gonzalez-Elvira's Luxembourg-based Calach Films. In other respects, the film follows the familiar trajectory found in the majority of sport film texts of the underdog (usually male) athlete who attempts to overcome, (at least temporarily), considerable personal and professional challenges through the achievement of some degree of sporting success. Here, the focus is on domestique Dominique Chabol (Louis Talpe) who at 38 is riding what is likely to be his last Tour de France (an ongoing anxiety) in the rather thankless role of a support rider to the team leader, in this case the arrogant and unstable Italian, Stefano Drago (Timo Wagner). There is also the inevitable love interest, though the underdeveloped role of race doctor Lynn Brennan (Tara Lee) and her relationship with Chabol is a particularly risible example of this trope. The film's largely fictionalised narrative is (as has often featured again previously in the genre) placed in relation to an actual sporting moment, in this case the opening stages to the 1998 Tour which took place in Ireland. Cue ample opportunities to foreground further familiar tropes, including shots of the extraordinary Irish landscape (which riding through the Wicklow mountains facilitates), Irish music, Irish dancing, the Irish pub (and its quirky array of characters) and (God help us) boyzone.

The initial Tour stages in Ireland were undoubtedly noteworthy at the time, particularly for Irish people who recall those days (as I do) as heady times indeed, and perhaps a final moment of national excitement (and innocence) in Ireland's extraordinary engagement with Le Tour which reached its peak in the previous decade with the successes of both Sean Kelly and Stephen Roche (a winner of the Tour de France in 1987). Roche was central (along with then President of the UCI Road Commission Pat McQuaid) in bringing the race to Ireland. However, the ' 98 Tour is most remembered today for bringing the use of banned substances by riders (including allegedly Roche during his career (O'Donovan, 2004)) to international attention. Three days prior to the start, Team Festina's soigneur (masseur) Willy Voet was discovered by customs officials at the Belgian border carrying large quantities of controlled substances (including erythropoietin (EPO), growth hormones, testosterone and amphetamines) and syringes in his car and this event arguably overshadowed for many the events in the race itself. Though no riders were found doping during the race, this was more a reflection of the inadequate testing regime in place at the time than actuality on the ground.

A comparable "Willy Voet moment" is briefly mentioned in The Racer, though referred to as "Settosa's soigneur [...] Manni Torche"; here as elsewhere in the film actual team names and individuals featured in the 1998 Tour are fictionalised (understandably given the depiction of drug-use in the sport). However, the central role of a soigneur in providing banned substances to team riders is foregrounded through the central character of team Austrange's (for which Chabol rides) soigneur "Sonny" McElhone (Iain Glen). The film chronicles in some detail this aspect of cycling in the period concerned, particularly in its 
detailed depiction of Sonny's work with team riders in preparing and delivering their performance enhancing cocktails. There are also suggestions of the devastating physical impact these substances had on the riders concerned; Chabol's heart almost stops while sleeping on several occasions due to his extraordinarily low resting heart rate as a consequence of EPO use. There is also a rather pessimistic view offered of the use of such substances in the sport; the one young rider who refuses to do so - French rookie Lionel Dardonne (Warm Kerremans) who insists on riding "clean" - is essentially blacklisted and attacked by other team members. Chabol himself ultimately decides to continue to use these substances, winning a stage in Ireland, and travelling with the other riders to France for subsequent stages, despite his threat to leave his team and the race in disgust at these practices.

However, none of these sequences bring anything new to the depiction of cycling the abuses in the sport have by now been well chronicled including in former Irish Pro cyclist Paul Kimmage's fascinating and revelatory Rough Ride (initially published in 1990), a brutally honest and excoriating account of the Tour and the widespread (and seemingly accepted) practice of doping in the 1980s. The past year also saw the release of a further relevant cycling documentary (one of many now available on the subject), the ESPN production Lance directed by Marina Zenovich, which focuses on the most corrupt exploiter of banned substances, Lance Armstrong. Armstrong was also the subject of Stephen Frear's much superior 2015 feature The Program (a further, in this case French/British, coproduction), which also included much more detailed and impressive sequences of cycling than apparent in the rather short (if competently realised) cycling scenes in The Racer.

What is most distinctive here, however, is The Racer's foregrounding of its Europeanness. This is most obviously apparent in the range of nationalities featured in the film, including Belgian, Scottish, English, Portuguese, Italian, French, Luxembourger, and Irish, while Chabol's team also features a New Zealand rider. However a further still more unusual feature (as regards sports cinema) is the diverse use of language: Chabol is (at least) trilingual, moving between French and English with team members, and speaking his native Flemish in conversations over the phone with his sister regarding his father's passing, just prior to the start of the Tour. Other languages featured include Italian, and (briefly) Spanish and Portuguese - even Irish has its moment as we hear the Aer Lingus pilot share his 'cúpla focal' as the plane carrying the riders to Ireland makes its final descent. Language and multilingualism was a founding principle of the EU and have been a key concern throughout its history, evident in its recognition (and facilitation at considerable expense) today of 24 official working languages. This is, indeed, a striking and commendable feature of The Racer, in its foregrounding of linguistic diversity with lengthy non-English speaking sequences in a variety of languages in a genre that is not renowned for this practice. It reflects broader concerns with foregrounding international and intercultural encounters within European coproduced sport cinema. However, in its reliance on familiar signifiers of both genre and place, The Racer may also speak to one of the biggest challenges of both European co-productions and perhaps the European project itself; how to define itself as a distinctive and engaging shared cultural experience for both audiences and citizens.

\section{Works cited}

Ashton, T. Soccer in Spain: Politics, Literature and Film. Toronto: The Scarecrow Press, 2013.

Crosson, S. "Sport, Film, and National Culture: An Introduction". Sport, Film, and National Culture, Ed. Seán Crosson. London: Routledge, 2021. 1-17.

Crosson, S. "Films, Festivals, and Football: Understanding European Sport Cinema". 
Keynote Address to the Annual international conference of the European Popular Culture Association (EPCA), EUPOP 2019, Mary Immaculate College, University of Limerick, 17 July 2019.

O’Donovan, C. (2004) "CYCLING : Roche fury at drug smear", Irish Independent, March 26

March 2004. https://www.independent.ie/sport/cycling-roche-fury-at-drug-smear-

26013897.html

\begin{abstract}
Notes
${ }^{1}$ I want to acknowledge the as always insightful advice and feedback of Dr Tony Tracy in preparing this review. I am grateful to Tony also for his invitation (some 15 years ago!) to contribute to this important annual review of Irish cinema, which he initiated, and which has become a critical resource for all of us engaged with the topic.
\end{abstract}

Seán Crosson is Senior Lecturer in Film in the Huston School of Film and Digital Media and leader of the Sport and Exercise Research Group, National University of Ireland Galway. His previous publications include the monographs Gaelic Games on Film: From silent films to Hollywood hurling, horror and the emergence of Irish cinema (Cork University Press, 2019), and Sport and Film (Routledge, 2013) and the collections Sport, Film and National Culture (Routledge, 2021) and (as co-editor) Sport, Representation and Evolving Identities in Europe (Peter Lang, 2010).

sean.crosson@nuigalway.ie

\title{
Sea Fever (Neasa Hardiman, 2019)
}

\section{Jack Fennell}

Neasa Hardiman's feature-length debut stands in marked contrast to the colourful and bombastic television properties she had directed previously (including episodes of Tracy Beaker Returns for the BBC, Amazon Studios' Z: The Beginning of Everything, and Marvel Studios' short-lived Inhumans). Sea Fever takes a science-fiction/horror premise that the viewer will find familiar from the likes of Alien, Event Horizon and John Carpenter's version of The Thing - and there are nods towards those films throughout - but Hardiman explores that premise in a remarkably sombre and contemplative way.

Hermione Corfield plays Siobhán, a $\mathrm{PhD}$ candidate researching the behavioural patterns of deep-sea fauna, who joins the crew of the fishing boat Niamh Cinn Oir to gather samples from the open sea. While following a radar reading of a large school of fish, the vessel is ordered to steer around an exclusion zone by the Coast Guard; due to financial problems, skipper Gerard (Dougray Scott) and his wife Freya (Connie Nielsen) decide to ignore the order and pursue their catch through the forbidden area. In so doing, they draw the attention of a massive, unidentified animal, which latches onto their hull and secretes its microscopic spawn into their water filtration system. As the crew try to make their way home, their situation becomes increasingly desperate.

Much of the popular discussion around Sea Fever has tended to focus on its apparent "timeliness", having been released at the onset of the global Covid-19 pandemic, but while the commentary has zeroed in on the obviously resonant plot points of quarantine, infection and a rapidly spreading invasive organism, few reviewers have married this reading to the 
theme of a changing ecosystem. Indeed, ecological balance seems to have been the intended core theme of the film, which was completed before the coronavirus exploded into the public consciousness and eclipsed discussions of climate change: Siobhán argues for the necessity of a quarantine by using the example of invasive ant species decimating red crab populations on Christmas Island, and against killing the creature on board the boat by saying that "it's just in the wrong place". Absent any direct explanation for the creature's emergence, the audience is left to infer that environmental changes in its usual niche have driven it into contact with humanity, in much the same way that zoonotic diseases will become more prevalent as isolated ecosystems come under increased pressure from human activity. Siobhán's reason for joining the boat's crew in the first place is to look for displaced deep-sea animals in their catch, which may account for her Ripley-esque insistence on protocol in the face of angry opposition from her crewmates: she is a scientist who has found exactly what she was looking for.

From the outset, though, the standard trajectory of this kind of monster movie is refuted. Siobhán and engineer Omid (Ardalan Esmaili) are the only ones on board with any kind of scientific training (with the others recoiling in superstitious disgust from Siobhán's red hair), and they try a number of improvised techno-fixes that, in another film, might well have bought them some time; here, however, their efforts are in vain. As the token scientist on board, Siobhán might be expected to work out what their assailant is, and thus, how to defeat it; however, beyond the reach of any network and armed with just a microscope and a laptop, she can only guess that it is "some kind of cnidarian," and her suggested solutions repeatedly prove inadequate. Other deviations from the standard plot abound: the first character to die is the amiable love-interest; the protagonist has no interest in killing the monster, and there is no hint of any conspiracy - rather than a cover-up attempt, the exclusion zone is for the benefit of a pod of calving whales, implied to be the creature's usual prey.

More importantly, Sea Fever deviates from the standard "monster in the house" film in terms of its tone. There are no heroic triumphs or thrilling victories on offer here: the only thing the crew can do is make for dry land, and even then, Siobhán fights to prevent them from going ashore until they can be sure that none of them are contaminated. Rather than rugged survivors overcoming impossible odds, these characters are defined by their regrets, self-doubt and past traumas. The boat is named after Gerard and Freya's deceased daughter Niamh (Cinn Oir or "golden head" referring to her blonde hair), and the figurehead is painted to resemble her; the circumstances of her death are not discussed, but Freya makes a pointed reference to drowning and Gerard has a noticeable scar on one side of his head. Crew member Ciara (Olwen Fouéré) alludes to having lost the rest of her own family, while Sudi (Elie Bouakaze) is in love with a woman who is unaware of his feelings for her; Siobhán struggles with loneliness that she does not know how to express, and Omid, in spite of his impressive engineering skill, is unable to find a better-paying job to support his wife and children. The characters all understand, on some level, that they are doomed. Quiet despair is a tough thing to get right, but the cast all deliver nuanced and affecting performances - from Scott privately admitting his feelings of guilt, to Sudi facing his own mortality, to a demoralised Freya abandoning ship. Interestingly, the goriest onscreen death is reserved for the only happy-golucky character in the cast; viewers who are particularly sensitive to the "injury to eye" motif will find this uncomfortable viewing.

Visually, the film for the most part is matter-of-fact and filmed in natural light. The lighting, palette and texture of the cinematography communicate the feeling of a low-key drama and emphasise the mundane: all the better to contrast with the anomalous monster, of course. The monster itself is only partially shown, in a scene where Siobhán dives underwater to inspect the damage to the hull, and sees scores of bioluminescent tendrils radiating from an unlit body in the dark. The visual dichotomy between the surface world and the depths is 
further underlined by the "dirtiness" of the sea: in every underwater shot, the water is full of shredded kelp and sundry particulates, and the water churned up by the boat's engines, filmed from below, looks almost like smoke. The contrast between above and below also applies to the set design of the boat itself - above decks, the Niamh Cinn Oir looks like any other fishing vessel of its size, while below, it opens out into a number of spaces that seem bigger than they should, with Omid's unique water filtration system being a focal point for much of the action.

An interesting variation on the subgenre, Sea Fever evokes the sciencefiction/survival-horror film without indulging any of the attendant clichés, and ends up being something rather different: whereas horror films are driven by characters who believe they still have some slim hope of surviving, the fatalistic tone of Sea Fever means that ultimately, the viewer ends up watching a cast of sympathetic characters coming to terms with the inevitable. Whichever broader significance one reads into the film's plot - Covid-19, environmental collapse, or something else - the mood will render it all the more disturbing.

Jack Fennell lectures in the School of English, Irish and Communications at UL, and is the author of Irish Science Fiction, Liverpool University Press, 2014, and editor of A Brilliant Void, Tramp Press, 2018.

jack.fennell@ul.ie

\section{State of the Union: The New "Shooting Crew" Agreement}

\section{Denis Murphy}

Employment relations between film crews and producers are hardly the most glamorous aspect of the Irish screen industries. They attract little attention from observers, despite their crucial importance to the successful functioning of the sector, both as a creator of cultural and commercial content and as a workplace. It was hardly front page news, then, when the trade union SIPTU and the producers organisation Screen Producers Ireland (SPI) announced in December that they had reached a new agreement covering work conditions and minimum pay rates for live-action film and TV productions. This new "Shooting Crew" agreement, in effect from January $1^{\text {st }}$, has had a fascinating gestation. Ten years in the making, its conclusion followed an extraordinary explosion of film worker activism over the previous two years, involving a suite of "players" well beyond SPI and SIPTU. The cast in this longrunning saga features a host of new film worker organisations, including over 20 guilds fraternal associations of screen workers with particular skills (e.g. editors, hairstylists, set decorators, etc). It also includes the more controversial Irish Film Workers Association (IFWA), whose high-profile opposition to producers and unions alike inspired a newfound sense of urgency between the workers and employers covered by the 2020 pact. In this brief article, I examine some of the new agreement's more notable aspects, before reflecting on the events that accelerated its path to completion.

The December announcement followed a decade of on/off negotiations to update the previous agreement, from 2010, which had run into problems from day one. Following a change of leadership immediately after that document was signed, SPI effectively withdrew its commitment, questioning the constitutionality of a "closed shop" clause requiring shooting 
crew members to join SIPTU. While this claim was never tested in the courts, the agreement was seriously undermined. Its more aspirational aspects, including a pledge to work towards creating an industry-wide pension scheme, never got off the ground. Despite these problems, the agreement continued to shape the employment relationship for most shooting crew members. It crystallised a number of practices that had emerged in the previous decade, such as a standard working week of 50 hours. It allowed production companies to make "all-in" deals with a fixed weekly rate, simplifying overtime arrangements. It also introduced a tiered system of pay rates, linking minimum remuneration to the scale of the production - a formal acknowledgment of the substantial differences between lower budget productions for the indigenous film and TV market and the more expensive international productions filming in Ireland with generous production subsidies from the Section 481 tax credit scheme.

How does the new agreement differ from its predecessor, and what are the implications for the industry?

\section{Grade expansion}

The 2020 agreement defines minimum pay rates for SIPTU members in some 93 grades, doubling the scope of the 2010 version. The new grades listed in the document (some 47 in all) reflect the influence of the numerous industry guilds established in the past two years, as discussed below. Pay rates for many new assistant and junior roles are established, reflecting, perhaps, a more formal progression path from trainee status to the full grade. This path has proved contentious in recent years, spawning new provisions in Section 481 legislation to improve the treatment of trainees and the quality of on-set training provided. Guild influence on the new agreement is also reflected in coverage of production departments not previously included, like Visual Effects (VFX), and the greatly expanded list of grades in other departments, such as Accounting, Casting, and Art Direction.

\section{Pay rates}

While the 2010 agreement provided separate pay rates for small, medium and large-scale productions, the 2020 version introduces a six-tier system, ranging from "Micro" to "Super" budget categories. For micro-level films (budgets up to €750,000) or TV projects (up to $€ 250,000$ per hour), all rates for all grades are negotiable, subject to a minimum of $€ 615$ for the standard 50-hour week. Large scale productions ( $€ 4-25 \mathrm{~m}$ for film, $€ 1.5-€ 8 \mathrm{~m}$ per hour TV) command much higher minimum rates, ranging from $€ 700$ at the trainee level to above $€ 2,000$ for the highest paid grades. Films and TV with budgets above these levels (the "Super" category) command minimum rates that are three percent higher again.

The number of productions on which these higher minimum rates will be payable, however, is likely to be small. Of the 95 film and television productions granted Section 481 support in 2020, only 23 attracted a credit of $€ 1$ million or more, indicating budgets that would place them at least in the "Medium" category.

While Revenue data don't reveal the precise Irish spend on these productions (ostensibly for reasons of commercial sensitivity), it is likely that only a handful had budgets in the "Large" category. It is not even clear whether Foundation, the Apple TV sci-fi series currently filming at Limerick's Troy Studios after a pandemic-induced delay, is large enough to trigger the "Super" budget wage premium. Widely reported (without evidence) as the most expensive production ever shot in Ireland, its listed tax credit of $€ 10-30$ million would need to be at the top end of that range to imply a per-episode spend large enough to exceed the $€ 8$ million ceiling.

The new agreement abandons the "all-in" 50-hour weekly rate formalised in the 2010 
version. The clause had a stated caveat that it should be an optional arrangement, and not be used to arrive at a weekly wage lower than would otherwise be payable. Its disappearance suggests some dissatisfaction with its operation, most likely from the film worker side of the arrangement.

\section{Industry pension}

Perhaps the most notable feature of the 2020 agreement is the long-overdue establishment of a screen industry pension scheme, modelled on arrangements in the construction industry, which has a similar employment structure heavily dependent on freelance and self-employed skilled workers. While full details have not been announced, it appears that the scheme will be administered by CPAS, the Construction Industry Federation's pension subsidiary. The proposed arrangement demonstrates the validity of SIPTU's longstanding insistence that such a system was both necessary and possible. Interestingly, SIPTU's press release announcing the 2020 agreement omitted any mention of pension arrangements. ${ }^{2}$ This omission suggests that there are still important details to be ironed out - including, perhaps, the matter of employer contributions. Hopefully, this important question will be clarified when and if production levels return to post-pandemic norms.

\section{Other changes}

The new agreement reflects the development of new studio infrastructure since the previous agreement, with provisions for travel and location expenses updated to reflect production activities at Troy (Limerick) and Ashford (Wicklow) studios. In general, expenses allowable are more generous than previously, with travel beyond $25 \mathrm{kms}$ from the studio or production base now usually subject to expense payments, compared with $40 \mathrm{kms}$ in previous iterations. For some grades, a new "box allowance" will formally compensate certain crew members using their own tools and equipment in the course of their normal work. While there are many other modifications to the agreement, most other clauses remain broadly similar to previous agreement(s). There is a formal commitment by producers to provide the structured industry training that is in any case required under Section 481 regulations. In terms of scope, the agreement applies to live action productions only. These productions may be for film, television or streamed distribution. Irish-language drama produced or part-funded by TG4 is excluded, unless budgets are above those in the "Micro" category - implying that micro-level TG4 projects have no wage obligations beyond the statutory minimum wage.

\section{Concluding thoughts}

As suggested above, progress towards the new agreement was greatly boosted by momentum generated by the newly established industry guilds. These new organisations began to emerge in 2018, largely in opposition to IFWA, a highly vocal group representing set construction and some other grades working mainly on the international TV productions based at Ardmore and Ashford Studios (Murphy). IFWA had made a high-profile appearance before the Oireachtas Culture Committee in early 2018, accusing producers of illegal employment practices, health and safety breaches, abuse of Section 481, and other concerns. The claims, some of which appeared highly questionable, generated a notable amount of social media traffic. They were also covered in the traditional media, not normally a site of critical coverage of industry funding and practices. When the IFWA claims were supported and amplified by the People Before Profit TD Richard Boyd Barrett, who also drew attention to the high levels of public subsidy enjoyed by the industry, concerned screen workers mobilised 
to counter the message. Under the coordination of the umbrella group Screen Guilds Ireland (SGI), over twenty different guilds were established. SIPTU recognised the opportunity presented by this new wave of worker activism, and embraced the moment. Guild members were encouraged to join or re-join the union on favourable terms, with the understanding that they could contribute to ongoing efforts to update the "Shooting Crew" agreement. It is likely that SPI, the main target of the IFWA claims, was also motivated to neutralise the perceived new threat to industry stability. Negotiations, stalled on several occasions over the previous years, were enthusiastically recommenced. Screen Ireland also weighed in with support, providing SGI with sufficient funding to employ a full-time organiser and part-time admin staff - mirroring supports also provided to the writers and directors guilds, and indeed SPI itself. $^{3}$

Although SPI counts animation companies among its membership, the agreement (like all previous versions dating back to the first negotiated producer-union agreement in 1988), does not cover animation productions, a significant and growing sector of the Irish screen industries. There are thus no standard pay rates for animation workers. Recently, however, there have been efforts to unionise animation workers through an organisation called Animation Workers Ireland. ${ }^{4}$ Although not a union itself, it has affiliated with the Financial Services Union to further this goal.

The 2020 Shooting Crew Agreement is a sign of improving industrial relations in the Irish screen industries. It is highly ironic that progress towards its finalisation was catalysed by IFWA, an organisation whose activism was also instrumental in bringing about the improved Section 481 training arrangements mentioned above. While there is little doubt that IFWA's profile in recent years was amplified by the decline in traditional trade union membership, that situation now appears to be in reverse. The size of SIPTU's Film and Entertainment branch membership is not clear, as the union has stopped publishing such figures in 2002, following a substantial decline since their mid-1990s peak. It is likely, however, that the positive relationship with SGI (which claims to represent some 2,000 film crew across its constituent guilds) has occasioned a substantial increase in union membership. ${ }^{5}$ SIPTU's renewed strength, aligned with the vibrancy of the Guilds and a seemingly smoother relationship with SPI, suggests a notable industrial relations improvement, reversing a situation that some considered detrimental to the long term viability of screen production in Ireland (e.g. Joint Committee 15).

The 2020 Shooting Crew agreement is testament to that improvement. It must be noted, of course, that its finalisation came about during the forced decline in production activity during the Covid-19 pandemic. It remains to be seen how the agreement, and its ancillary arrangements like the industry pension scheme, will work in practice, if and when production levels returns to their previous norms.

\footnotetext{
Notes

${ }^{1}$ Extrapolated from Revenue Commissioners (2021).

2 https://siptu.ie/media/pressreleases2019/mainnews/fullstory_22184_en.html

3 See Screen Ireland (2020). It is unclear if this funding was continued in following years, as Screen Ireland has yet to publish its 2019 and 2020 annual accounts.

${ }^{4}$ Animation Workers Ireland (2020).

${ }^{5} \mathrm{https}: / /$ twitter.com/screenguilds
}

\section{Works Cited}

$\begin{array}{lllll}\text { Animation } & \text { Workers } & \text { Ireland, } & \text { Online } & \text { survey. }\end{array}$ https://fsusurvey.typeform.com/to/k0djHtZ7 (Accessed 27 Jan 2021). 
Joint Committee. Development and working conditions in the Irish film industry. Dublin: Joint Committee on Culture, Heritage and the Gaeltacht, 2018.

Murphy, D. "Fear, Loathing (and Industrial Relations) in the Irish Film Industry." Estudios Irlandeses 14 (2019): 321-4.

Revenue Commissioners. "Beneficiaries of tax relief under S481 Film Relief Scheme 20162020." https://www.revenue.ie/en/companies-and-charities/documents/beneficiariesof-tax-relief-from-2016-2020.pdf (Accessed 27 Jan, 2021)

Screen Ireland. Annual Report and Financial Statements. Galway: Screen Ireland, 2020.

Denis Murphy is a Government of Ireland Postdoctoral Research Fellow at the Department of Film, School of Creative Arts, Trinity College Dublin, where he also lectures.

denis.murphy@tcd.ie

\section{Wild Mountain Thyme and the Moral Panic around the Irish Accent on Film}

Nicholas O'Riordan

\section{"No Irishman ever talks like that in Ireland, or ever did, or ever will" Larry Doyle, John Bull's Other Island}

Cinematic representations of Ireland have predominantly been the output of foreign filmmakers, undoubtedly influencing the approach to representation in many films. While many aspects of the filmic representation of Ireland and the Irish have been criticised including images of violence, the recurrence of the "stage-Irishman", and the romanticisation of the Irish landscape, no aspect of Irish film has been subject to more sustained and common popular criticism than the representations of Ireland's accents. This perceived misrepresentation of Irish accents has become particularly synonymous with American representations of Ireland. In fact, American films set in or about Ireland, such as The Quiet Man, Leap Year and P.S. I Love You, are commonly known to Irish viewers as "Oirish" films, with phonetic spelling marking the perceived stereotyping of accents often heard in such texts. A Google search of the words "Irish", "Accent", and "Film" generates pages upon pages of recent critiques of performances of Irish accents in film such as The Worst Irish Accents in Hollywood Movies, ${ }^{1}$ Top 10 worst Irish Accents in Movies (Wickham), and The 12 Absolute Worst Irish Accents in Movies Ever (Demolder), while television, radio and national print media often create content criticising accent performances in Irish film.

While lists such as these appear online and in print media every march around St. Patrick's Day, the performances referenced are invariably pre-2011, with a majority from the 1990s. In response to the proliferation of bad accent lists, many commentators have noted that "overseas actors have got steadily better at proper Irish accents", with several lists published recently commending "great" recent Irish accent performances. While criticised performances are increasingly a thing of the past, responses to 2020's film and television has reignited the moral panic surrounding Irish accents in film. While the year saw Irish audiences praise British actors Daisy Edgar-Jones in Normal People (Element Pictures, 2020), Cosmo Jarvis in Calm With Horses (Nick Rowland, 2019), and Tom Glynn-Carney in Rialto (Peter Mackie Burns, 2019), the latter months of the year saw widespread dismay at accent performances in 
the trailers to Wild Mountain Thyme (John Patrick Shanley, 2020), and to a lesser extent, Pixie (Barnaby Thompson, 2020).

On the release of the Wild Mountain Thyme trailer in November 2020, social media interest in the film's accents grew quickly. Primarily perceived as perpetuating tired IrishAmerican "stage-Irish" film tropes, the trailer's accents generated responses of anger, confusion, and humour. High profile examples of these humorous responses included Dublin Airport tweeting "There's a fashion police, grammar police, we even have airport police. Is there such a thing as accent police? If so, somebody better call 'em", and the Leprechaun Museum, Dublin tweeting "Even we think this is a bit much". Media outlets including Euronews, $B B C$, and The New York Times reported on this growing negative reaction to accent in the film, quoting social media users' comments and reminding the reader of previous controversial Irish accents in film. Irish media interest was particularly prolific, and at the time of writing, between The Irish Independent, The Irish Times, and The Irish Examiner, 20 articles on the reactions to accents in the film have been published, with many other outlets similarly publishing multiple articles on the subject.

Adding to the discourse surrounding the film's representation, in an interview with Variety, Wild Mountain Thyme's Irish-American director John Patrick Shanley noted he was "not making this movie for the Irish. [He was] making this movie for everybody else and all the people who want to go to Ireland" (Murray). Although many factors influence accent performance and accent reception, "misperformed" accents are often perceived as an issue which occurs almost exclusively when Irish accents are performed by non-Irish actors. ${ }^{2}$ However, this perception is disrupted somewhat by responses to Irish actor Jamie Dornan's accent performance in Wild Mountain Thyme. In defence of the film's accents, Shanley argues that "if the characters sounded exactly as his relatives spoke, no one would understand them", stating that "[y]ou have to make the accent more accessible to a global audience" (Murray). This approach to accent is not a new one. Many directors, producers and actors have equally expressed this motivation to "tone down" regional accents. Actor Minnie Driver, in an interview on RTÉ's The Late Late Show in $1995,{ }^{3}$ notes a pressure from studios to "tone down" accents in Circle of Friends (Pat O'Connor, 1995), stating "Hollywood was like, you know, "we can't have a [The] Commitments, nobody could understand a word they were saying" (that film, released four years earlier, utilises a range of north Dublin accents often perceived as more regionally marked). ${ }^{4}$ Many Irish actors working outside of Ireland, including Jack Reynor and Alan Smyth, have expressed similar motivations to "tone down" accent. In what could be read as support for such approaches, in the weeks after the release of Normal People, several media outlets published articles on American viewers' "admitting" to watching the show with subtitles, with many viewers using subtitles to interpret the regional Irish accents in the text. Similarly, British audiences have reported similar issues in the accent performances in The Young Offenders this year, and in recent years the Netflix global release of Derry Girls led to similar articles.

The process of "toning down" accents for audiences can be read as a form of Hollywood's "self-dubbing", whereby the "English will be spiced with some of the accent and idioms of the original language to foreground that the characters are foreign" (Kozloff 81). In Hollywood cinema, "given the pressure on filmic speech to help carry the narrative forward, the presence of non-English speaking characters creates a conundrum" (Kozloff 80) and while in the current context, we are not dealing with two disparate languages in the traditional sense, many of the same operations are at play in the current context. Writing on the US same-language dubbing of Mad Max, whereby the studio "sought to assimilate cultural difference by removing its regionally Australian English", Tessa Dwyer draws upon Hamid Naficy in arguing that "this process opened up a new cross-cultural space or arena, imbuing the film with additional, unintended layers of meaning [providing] pleasurable 
opportunities to speak back to films by renegotiating meanings and cultural references" (150). While Hamid Naficy points to the moviehouse as primary site of this negotiation (183-202), the space of exhibition for the Wild Mountain Thyme trailer was largely social media. Users voiced anger, frustration, humour, and bewilderment at the trailer's accents with many further disseminating the video accompanied by comments often exaggerating the accents in the trailer. Other users produced re-dubbed, or home-made versions of the trailer, or parody audition tapes in stage-Irish accents. Since the film became available online in some regions several Twitter users, including popular Irish novelist Marian Keyes, have humorously livetweeted their first viewing, with more online watch-along parties planned for, at the time of writing, the upcoming official Irish release of the film.

Due to the history of perceived misrepresentation and the proliferation of such accent criticism, accent is almost always addressed in any Irish media review of a film with a nonIrish actor performing a role. Three weeks prior to the release of Normal People, Bustle ran an article which looked ahead to the adaptation of Rooney's "much-loved novel". Noting that the "Irish accent is notoriously difficult to master for most people not hailing from the emerald isle. As an Irish woman, I can certainly attest to this" (Hanna). This article pre-emptively opens up questions of accent performance in the adaptation due to a history of challenged accent performances. While a common popular perception is that Irish accents are relatively difficult accents to perform, many performers and accent coaches disagree with this, as renowned Irish accent coach Brendan Gunn asserts: "the idea the Irish accent is too hard to replicate is a myth" (Horgan). As Christopher Holliday notes, the "ability of an actor to adopt a specific national dialect has been imbricated within what Paul McDonald labels "the spectacle of prestige performance" and the "show of actorly craft" (Holliday 66), conditioned by "personal commitment" and this year, actors Edgar-Jones, Jarvis, Glynn-Carney, Ben Hardy, and Olivia Cooke have all received acclaim for their accent performances, with audiences often expressing shock upon hearing each actor's "real" accent. During promotions duties for their respective texts, each of these actors were asked actors about their Irish accents, with several noting the pressure to "get it right" due to awareness of the host of "worst Irish accents in film" lists, and the often negative reactions these performances receive from Irish audiences. Interestingly, while the stars of Wild Mountain Thyme discussed their preparation for accent performance in the film, the film's accent coach, the aforementioned Brendan Gunn, noted that he did not meet with the cast in person, with producers opting to rely on recordings he had made for them (Horgan). Gunn explained that "this rarely works [...] It's the first time in my career that I didn't get to speak to the cast which I found most unusual" (Horgan). While perceived accent issues cannot to attributed solely to this, it does demonstrate the differing approaches of film productions to accent performance.

While cinematic representations of Ireland and its accents have often been met with criticism, the extent to which Wild Mountain Thyme's accents have sparked discussion and how this discussion was so widely reported on, is unprecedented. Although, as Kevin Rockett noted in 2012, "[t]here has [sic] been far more films made about the Irish by American's [sic] than the Irish themselves" (Hall), a growing wave of indigenous Irish productions works to redress this balance. Representing images of Ireland far removed from the "picture postcard" images of classic Irish American cinema, this wave of filmmakers, as I have noted elsewhere (O'Riordan "Don't Use", "The Voices"), have increasingly utilised accent politics as central to various aspects of texts. Ruth Barton notes that "[i]t's not that long ago that we were fighting to take control of our own image and tell our own stories and we still take it badly when other people claim to speak on our behalf or try to claim our identities" (Maguire). As the space of exhibition, distribution, and discussion for these trailers, and increasingly, films, social media facilitates a playing with texts, mediating their distribution and reception by other viewers in real time, "transform[ing] the cinema's "work" from one of hailing to 
haggling" (Naficy 191). Although there remains a situation whereby in some representations of Ireland "language becomes merely functional as the inherent subtleties of accent are sacrificed in order to make Irish films as accessible as possible to international audiences" (Crosson 10), the wealth of contemporary indigenous Irish film and screen media serves to lessen the impact of such contested representations on the national cinema.

\section{Notes}

${ }^{1}$ See "The Worst Irish Accents in Hollywood Movies".

${ }^{2}$ While rare, performances of Irish accents by Irish actors including Liam Neeson and Pierce Brosnan have been met with criticism.

3 See The Late Late Show "Circle Of Friends Stars 1995", video, https://www.rte.ie/archives/2020/0421/1132864-circle-of-friends/

${ }^{4}$ Interestingly, The Commitments played on the linguistic distance with by releasing $A$ Tosser's Glossary, a guide to slang terms mentioned in the film, as both humorous souvenir and as a translation device.

\section{Works Cited}

Crosson, Seán. "Vanishing Point: An Examination of Some Consequences of Globalization for Contemporary Irish Film." E-Keltoi: Journal of Interdisciplinary Celtic Studies 2.1 (2003): 1-23.

Demolder, Kate. "The 12 Absolute Worst Irish Accents in Movies Ever." Lovin.ie, June 2, 2017. https://lovin.ie/news/feature/the-12-absolute-worst-irish-accents-in-movies-ever

Dwyer, Tessa. "Mad Max, Accented English and Same-Language Dubbing." Locating the Voice in Film. Ed. Sarah Wright and Tom Whittaker. Oxford University Press, 2017. 137-55.

Hall, Eva. "Five Minutes with...Irish Film Historian, Kevin Rockett." IFTN. 3 May 2012. http://www.iftn.ie/news/?act1=record\&only=1\&aid=73\&rid=4284889\&tpl=archnews \&force $=1$

Hanna, Aoife. "How Daisy Edgar-Jones Learned The Irish Accent For 'Normal People'." Bustle. 1 April 2020. https://www.bustle.com/p/are-the-actors-irish-accents-in-normalpeople-real-22680993

Holliday, Christopher. "The Accented American: The New Voices of British Stardom on US Television." Journal of British Cinema and Television 12. 1 (2015): 63-82.

Horgan, Niamh. "'I can't be blamed for those accents - I didn't even get to speak to the cast' says Wild Mountain Thyme voice coach." Irish Independent. 10 January 2021. https://www.independent.ie/entertainment/movies/movie-news/i-cant-be-blamed-forthose-accents-i-didnt-even-get-to-speak-to-the-cast-says-wild-mountain-thyme-voicecoach-39951627.html

Kozloff, Sarah. Overhearing Film Dialogue. University of California Press, 2000.

Murray, Eavan. "'I'm not making this for the Irish' - Wild Mountain Thyme director rejects critics." The Irish Independent. 12 December 2020. https://www.independent.ie/entertainment/movies/im-not-making-this-for-the-irishwild-mountain-thyme-director-rejects-critics-39852184.html .

Naficy, Hamid. "Theorizing 'Third Word' Film Spectatorship: The Case of Iran and Iranian Cinema." Rethinking Third Cinema. Ed. Wimal Dissanayake and Anthony R. Guneratne. Routledge, 2003. 183-202.

Maguire, John. "Why Hollywood gets the Irish so wrong." BBC.com. 11 December 2020. https://www.bbc.com/culture/article/20201210-why-hollywood-gets-the-irish-sowrong 
O'Riordan, Nicholas. “'Don't Use Your Own Accents!': Representations of Dublin's Accents in Contemporary Film." Ireland and Cinema. Ed. Barry Monahan, Palgrave Macmillan, 2015. 35-46

. "The Voices of Irish Identity: A Taxonomy of Cinematic Accents,", JCMS: Journal of Cinema and Media Studies 59.4 (Summer 2020): 173-7.

"The Worst Irish Accents in Hollywood Movies." Irish Central, 15 May 2017. https://www.irishcentral.com/culture/entertainment/worst-irish-accents-hollywoodmovies

Wickham, Conor. "Top 10 Worst Irish Accents in Movies." Ireland Before You Die, 27 November 2019. https://www.irelandbeforeyoudie.com/top-10-worst-irish-accents-inmovies/

Nicholas O'Riordan is a doctoral candidate in the School of Film, Music and Theatre at UCC. His research interests include Irish cinema, national cinemas, film theory, sociolinguistics and representations of group identity in film. His writing has featured in Film Ireland and in the edited collection Ireland and Cinema: Culture and Contexts, ed. Barry Monahan, Palgrave, 2015. He has co-organised international film conferences, and co-edited for Alphaville Journal of Film and Screen Media. He also works as a filmmaker.

nicholas.alphaville@gmail.com

\section{Vivarium (Lorcan Finnegan, 2020)}

\section{Emma Radley}

Lorcan Finnegan's second feature, Vivarium, made its public debut, inauspiciously, in March 2020, less than a week after much of the world entered lockdown due to the Covid-19 pandemic. Given the impossibility of any kind of theatrical release, the film was made available through various streaming services, and in fact, the lockdown itself provided a ready-made framework for the distribution company to play on in its marketing. After all, what could be more appropriate to capture the skittish ennui of the first days of quarantine, when everything seemed slightly unreal, slightly cinematic even, than a horror/sci-fi film that gives us a couple trapped in a very grim housing estate with a very demanding child, living the same day over and over, with no possibility of escape?

The plot and characterisation are spare: a young couple, played by Imogen Poots and Jesse Eisenberg, is searching for a home to buy. Everywhere is beyond their budget, or wrong in some unnamed way, until they wander into an estate agency staffed by a very strange man named Martin, who manages to convince them to have a look at a house in a brand new development called Yonder. They agree, though both of them are clearly horrified at the thought of living in suburbia - Gemma and Tom are a prosaic hipster couple, a gardener and a teacher at a bohemian, but clearly very middle class, school. Once they arrive at the house in Yonder, Martin shows them into number 9, and disappears while they poke sardonically around the garden. Gemma and Tom decide they've had a lucky escape, and head back to their car, but soon find that they are unable to leave: every turn they take in the labyrinthine development, brings them back to number 9 . After trying every avenue to escape, including burning number 9 to the ground but finding it, creepily, perfectly intact the next morning, they accept their fate as suburban citizens. They find a cardboard box outside, with a new- 
born inside, and a note reading: 'raise the child and be released'. Time ticks on, and Gemma and Tom become increasingly alienated, from each other, and from themselves: Tom develops an obsession with digging a large hole in the garden, and Gemma struggles to deal with the child, who grows preternaturally quickly, and appears to be some kind of demonic pod-person, replete with a skittering walk and a mysterious old book filled with arcane symbols. Suburban citizenship, indeed.

Lorcan Finnegan's previous work (also with writer Garret Shanley) demonstrates a particularly refined treatment of the Irish landscape, in ecological and political terms. Foxes, his first short film, released in 2012, has a somewhat similar premise to Vivarium: a young couple, living in one of the few finished houses in a ghost estate, slowly start to unravel. The woman, whose work as a photographer has dried up due to the recession, becomes fixated on an urban fox, following it through the development and taking pictures of it framed against the overgrown gardens and unfinished houses. The dystopic atmosphere of the ghost estate is perfectly realised in melancholic aerial panning shots, for example in the sharp contrast between the couple's perfectly manicured lawn and the environment of the spaces around them. Ellen's tracking of the fox takes her towards the increasingly atavistic fringes of the development, and indeed, civilised modernity itself - the film astutely captures the apocalyptic feel of the recessionary Irish landscape (both economic and physical). Finnegan's 2016 feature, Without Name, is a horror film about a land surveyor sent to evaluate some woodlands earmarked for commercial development, who - inevitably - begins to experience disturbing supernatural events. Here, Finnegan's portrayal of the forest has an eerie, and beautiful, gothic sensibility, and coupled with the ecocritical framework of the confrontation between nature, tradition, and modernity, Without Name is another cogent example of the compelling way that Finnegan and Shanley can engage and represent cultural anxieties around neoliberal habitus in contemporary Ireland.

In Vivarium, the suburban development of Yonder is likewise strangely, but compellingly, rendered, also using slow and ominous aerial shots of Gemma and Tom's car attempting the navigate the circuitous terrain of the estate. The visual composition of Yonder has a distinctly painterly feel, an aesthetic style intensified by the artwork displayed in number 9, which is all images of the house itself. This painterly feel is a digital one, rather than conventional brushstrokes: the perfectly uniform clouds that dot the skyline, the polychromatic sunset, the uncanny geometry of the houses in the development as they stretch into the horizon, all suggest something computer generated, something in the order of a simulacrum. But there's something raw and real underneath. The large hole that Tom digs in the rubbery garden soil, and in which he spends more and more time, becoming sicker and sicker, is an earthy, corporeal space, claustrophobic and in contrast to the manufactured and sterile environment above ground. At one point in the film, Gemma follows the demon offspring through a gap under the kerb, and plunges down through a range of other identical houses, filled with similar couples trapped in the same nightmare, weeping, having sex, selfharming - again, creating a jarring juxtaposition between the carnal humanity of Gemma and Tom, and the malevolent automatons, Martin and the Boy.

There's a lot going on in this film, despite its extremely circumscribed architecture. What does it all mean? Here, perhaps, it starts to unravel a little. On one level, it's a commentary on neoliberal, heteronormative, citizenship, and in this respect, follows the ideological underpinnings of Finnegan and Shanley's other work, Foxes and Without Name. Yonder represents the pinnacle and limit of contemporary middle-class desire and achievement (the billboard as Gemma and Tom drive in shows a multicultural family smiling in front of the front door of the ubiquitous number 9, with the tagline "You're home right now: Quality Family Homes, Forever"). Gemma and Tom eat vacuum packed, pre-prepared food, dropped off daily to their door in a carboard box like an upmarket meal subscription 
service; the goods appear luxurious (steaks, champagne, strawberries), but are devoid of real taste and pleasure. And of course, they raise the child, and then they die - in a monstrous intensification of heteropatriarchal circularity the fully grown offspring takes the place of Martin back in the estate agent, and waits patiently for the next house-hunting couple to arrive.

In some ways, the film is timely - the relentless tedium of the neoliberal treadmill is uneasily resonant with pandemic life, where neoliberal corporate culture insists that we all carry on as normal in profoundly abnormal circumstances: just keep going, never mind that your child might actually be a horrifying demon with a grotesque throat sac. In other ways, though, the film is strangely belated. The neoliberal critique, the rendering of the suburban phantasmagory, the incitement to get on the property ladder before the prices "go through the roof", all feel more 2006 than 2020. Of course, when the film was written and produced, the country was on the cusp of the Tiger, Part 2: the recovery in full swing, the ghost estates reanimating, the property market just starting to bloat. Still, from where we currently stand, in the pandemic-induced liminal space between the Before Times and the Unknown Future, Yonder seems out of place, both temporally and culturally (perhaps if number 9 was a tiny unit in a co-living development, it might have a more uncanny resonance).

Where the film is most effective, however, and most affective too, is in its depiction of the difficult and unspeakable facets of intimate relationships, both as a partner and as a parent, all horribly intensified in the oppressive domesticity in which we are currently existing. The film represents the uncanny in the true, Freudian, sense: in the unheimlich space of number 9, all manner of traumatic experiences unfold around the body of the demonic child (the 'primal scene', neglect, physical and psychological abuse). The darkest capabilities of parenting are particularly painfully imagined: the child screams unintelligibly whenever it needs something - food, rest, attention - and Tom and Gemma struggle to placate it: at various points, Gemma shakes it roughly, sobbing "what do you want?" over and over again, and Tom locks the child in the car, or punches it. These moments are unflinchingly horrific, magnified by the angelic appearance of the boy playing the younger iteration of the child (Senan Jennings), on whom all these violences are inflicted: his slightly lisping delivery, and strangely endearing fascination with making the "woof-woof" sound of a dog, always reminding the viewer that, veiny throat sacs or not, this is a child. Certainly, the film explicitly intervenes in the nature vs nurture debate around child development: on numerous occasions, we see the child mimic Gemma and Tom's arguments and emotions, in a disquieting and perverse display of internalisation and acting out. In this respect, Vivarium recalls other films that interrogate the horror of parental ambivalence, such as The Babadook (Jennifer Kent, 2014), and Lynne Ramsay's nihilistic 2011 adaptation of Lionel Shriver's We Need to Talk About Kevin. Gemma's struggles with her own reluctant, but insistent, maternal instinct are especially thought-provoking: in some ways, the film could be read as a nightmarish exploration of post-natal psychosis. The bleak final sequences bring the viewer back to the disturbing cold open, the story of the cuckoo who kills the nestlings and makes a surrogate of the mother bird (realistically, and distressingly, executed). The fully-grown child no longer has any need for Gemma, and, zipping her into a body-bag, tells her that she has fulfilled her role of child-rearing and can be released - a mother's duty is to "prepare her son for the world", and then die. Again, the psychoanalytic underpinnings of the film come to the fore: this is exactly the role assigned to the mother in the conventional, oedipal, framework of Freud, Lacan, et al. Gemma refuses this role: her final words are a repetition of her refrain to the child throughout the film, "I'm not your fucking mother". The response perhaps crystallises that of the viewer, searching for meaning in the film: "whatever", the man-childdemon shrugs. Like Yonder (and indeed, the pandemic), it's hard to see beyond the horror of the here and now. 
Emma Radley works in the UCD School of English, Drama and Film. Her teaching and research interests are in the area of Irish film and visual culture, psychoanalytic theory, and horror film and literature. She is the editor of Viewpoints: Theoretical Perspectives on Irish Visual Texts (with Claire Bracken, Cork University Press, 2013). She has published articles and book chapters in the areas of psychoanalysis, film theory, horror cinema, popular culture, and Irish cinema, literature, and culture.

emma.radley@ucd.ie

\section{"You Irish. You're fucking dark!" Dead Still (RTÉ 2020)}

\section{Sheamus Sweeney}

If nothing else Dead Still (2020) is a genuine attempt to play with Irish television's tendency toward generic imitation. A Victorian comedy-drama where the police chase porn peddling communists around Dublin was most likely not on anybody's list of expectations for 2020 . 2020 was nothing if not the year of the unexpected. It is its treatment of the dead that sets the series apart. If dark farce does not already exist as a genre then John Morton, the series creator and writer, seems to have invented it. In Dead Still, corpses are not simply set dressing or plot devices, their existence is the point, and the dead hang around from episode to episode. This is apparent from the beginning.

The dead female body, in particular, has been aestheticised to the point where it seems to have passed through established trope, to self-aware parody, to barely acknowledged set dressing. This has equally been the case with dramas from the Law and Order or CSI gene pool, as with the more lauded and gritty dramas like The Fall, Luther, or most of the Nordic noir output. So, there is something quite touching about a drama in which dead bodies take up screen time, as objects by definition, but as objects to be mourned and memorialised, rather than avenged or dismembered. This is established at the very beginning of the first episode, when Brock Blenner-Hassett (Michael Smiley) is seen speaking to his subject, seemingly exhorting her to look her best for a traditional family portrait. It is only then revealed that this portrait is a fiction intended to create the illusion of family togetherness and life. The principle subject is in fact a corpse, and she has died of natural causes.

True, there are a number of heavy handed analogues running through the series to contrast past and present, and to underline continuities. It also succeeds in making photography seem alien again, as a tangible and mechanical process. This goes beyond showing the actual labour and equipment involved in making a photograph. It re-establishes photographic practice not merely as a way to thoughtlessly capture a moment, but reminds us that manipulation and circumvention of reality has been present since its inception.

A recurring and somewhat unusual motif, is the desire of those left behind to memorialise their lost loved ones, not simply as individuals but as part of the life they shared together. This is the case with most of the families with whom Blennerhassett works, as well as for Roth, "the former convict, Fenian agitator, and enemy of the crown," in the first episode. There is a touching moment later in the series when gravedigger turned photographic assistant Conall Molloy reveals how Blennerhassett refused him a picture of his dead wife because he did not have the money to pay for it. 
There are a number of issues that hamper the show's six episode run. Like much RTÉ drama, it feels like a compromise between wanting to be an episodic drama and a serial. This leads to the series as a whole feeling unbalanced and unevenly paced. The main story arc rests on a pornography and snuff photography ring operating in late nineteenth century Dublin, possibly under the auspices of the hellfire club. It is both unsettling and funny. It is undermined by having to share narrative space with traditional "monster of the week" episodes. Twenty-two episode US network shows like The X-Files or Buffy the Vampire Slayer can support both. Dead Still is a short series with the ambition of a twelve or twenty episode series. It simultaneously feels like it is trying to do both too much and too little. The Jo Spain penned Taken Down (2018), about the murder of a resident in a direct provision centre, suffered from a similar problem. Properly paced and structured dramatic narratives seem to be particularly difficult to pull off in Ireland. It suggests a lack of resources invested in pre-production script development, rewrites, and editing.

Another element, albeit one that seems to be accidentally partially successful, is a somewhat cavalier approach to production design, which often seems slapdash and full of anachronisms. The cigarette lighter used by Nancy Vickers in the first episode looks suspiciously modern, and Blennerhassett's gramophone in the final episode seems dropped in from a later period. The series is set around the 1880s, but it often feels less Victorian Dublin and more an Irish version of steampunk. It leaves Dublin feeling both familiar and other worldly, an "othering" that underlines the alien atmosphere of a series set in a period underexplored by Irish drama. What sets it apart from a number of other recent RTE series is its relative originality, one of tone and mood, rather than format or genre. While it contains certain set pieces of gruesome body horror, it is toned down in comparison to Penny Dreadful or Ripper Street, both filmed in Dublin, and a seemingly conscious decision to play to the strengths of Irish television production. It almost feels like somebody noticed that Ireland has been doing producing generic period drama for the best part of a decade, with the set and costume designers with the skills to create a semi convincing $19^{\text {th }}$ century Dublin.

Dead Still takes place during the land war, which is referenced more than once, and both after the Great Hunger and on the cusp of the Gaelic revival. This is a period when the most prominent Dublin writers of the age, like Wilde and Shaw, were more inclined to write about the political and personal dramas of the English, than about the city of their birth. It is a city struggling with the shift to modernity, while dragging the past along with it. In fact, while the inclusion of communists, and American smut peddlers might seem random, it establishes Dublin not only as part of the United Kingdom, but as a place open to much wider forces and influences. Class and gender are far bigger sources of division than national identity, as is the conflict between Dublin and Cork. Conall Molloy is from the Monto (a famous red light district in north Dublin city), and Nancy Vickers is a proto feminist member of the AngloIrish ascendancy. Insofar as the clash between the British and the Irish is rehearsed, it is in the clash between enlightenment rationality and traditional superstition:

This is not the boglands. This is Dublin, part of the British Empire. How many changelings and pucas do you see roaming the streets? Leave that oul' blather to the Fenians. We deal in facts. Proof.

This is an admonition from Detective Regan's superior, and describes the perceived role of the Dublin Metropolitan Police, attempting to impose rational modernity in a city where a rising body count is attributable to a case which seems to have been dragged from the depths of Irish folk horror. The series gleefully draws from Irish popular history and folk legend. For example, the Hellfire Club, a debauched drinking society of popular lore, is repurposed into a shadowy cabal, trading in illicit images of the recently deceased. 
Dead Still is preoccupied with meaning, particularly the meaning we bestow upon images. The importance of context in which the images are experienced is crucial. How photographs possess meaning for the beholder, but also how this meaning is also dependent upon the pre-existing narratives brought to bear upon them. This is especially pertinent in the case of the death photography practiced by Brock Blennerhassett. There is little practical difference in the creation of a memorial photograph by Blennerhassett, and the creation of a photograph of a murder victim. This is shown in the obvious parallels between Blennerhassett's work, and the photographing of the killing of his nephew and the attempted killing of his niece, Nancy. The main difference is in presentation and purpose. In the former case, the illusion of peaceful passing, and even continuing life are central to the memorialisation. In the latter, photographs presumably created for the Hellfire Club, the presence of markers of violence on the corpse are central to the presentation, and to the pleasure experienced by the beholder. The images are moments in time, but they are moments either freighted with good memories and familial bonds, or with fear and violent death. A similar, if less explored, further example is Blennerhassett's contracting by Inspector Regan, as a proto-crime scene photographer. The dead and their memorialisation is far more present in this series than in other crime dramas.

The characters range from the fully drawn to the frustratingly under developed, another consequence of the short run, and another reason to hope that there will be a second, slightly longer, and better-paced season. Brock Blennerhassett is a photographer, and an estranged member of a declining Anglo-Irish family. Period drama is very often a place where women are given marginalised roles, often accompanied by the shrugging justification that that is just how things were. That is why one of strengths of Dead Still is how it manages to create historically realistic women, but who also occupy pivotal roles in the plot. Nancy Vickers is a wannabe actress, an ostentatious smoker, and possibly a proto Constance Markiewicz. References to Ireland's place within the empire are marginal but she gets one of the best lines, when asked by the Dublin Castle Detective Regan is she has seen any suspicious foreigners hanging around; "You mean apart from the British?" Betty Regan, wife of the Dublin Castle detective is saved from being a stereotypical domestic despot, by the genuine partnership with her husband, and the way he uses her as a sounding board for his theories. The fact that they are often both wrong, carried away by their flights of fancy, is beside the point. They discuss cases over breakfast and their theories while they jointly hang out the washing. In a nod to the interpersonal squabbles characteristic of the streaming age, the Regans' joint reading of The Moonstone is presented as modern couples may have watched shows like Breaking Bad, with irritation caused on both sides as one moves ahead of the other in the story. The historically plausible mother and daughter team of seance scammers provide more comic relief, and also undercut any suggestion that the series narrative takes the supernatural seriously. Similarly, Conall Molloy's foulmouthed sister is underused, but works especially well alongside Nancy Vickers.

So, what makes this series interesting, despite its shortcomings? For a start it is unusual and refreshing to see a Dublin depicted onscreen, that is neither post-Celtic Tiger steel and glass, nor dystopic gangland hellhole. The Dublin (and Wicklow) of Dead Still, is late Victorian, with an atmosphere that owes a lot to the popular fiction of the time. This is the Ireland of Bram Stoker and Sheridan leFanu. While the show is also cavalier in its use of anachronism, and recreates the period with broad brushstrokes rather than rather than painstaking exactitude, it is still bracing to see this Dublin. Dublin post-famine, a British city close to the heart of the United Kingdom and the British Empire, but also miles away from it, both geographically and in culture of terms. It has its own popular culture, one that as yet seems untainted by post-famine Catholicism and still capable of synthesising its own culture of death, and its own folk horror. 
It is also a place where the Monto (Dublin's infamous pre-independence red light district) plays a prominent role, not merely as a place to be visited (as for example in the work of Joyce) but as a place where people live and rub shoulders. One of the funniest set pieces involves Nancy Vickers (Eileen O'Higgins) attempting to gain information by going undercover as an unconvincing sex worker called Violet.

While it is not attempting to be a capital $\mathrm{H}$ historical drama, it is good to see stories rooted in the, admittedly outlandish, everyday life of Dubliners. Regan's obsessive pursuit of the photo ring is often framed as some weird quixotic irrelevance in a country where Fenians are running around and landlords are being hanged in the land war.

This Dublin is a place where communists, fenians, and pornographers rub shoulders with each other. It is a place where the story arc revolves around the attempt to take down a pornographic and snuff photo ring. Its cast of characters includes an American civil war veterans, the wonderfully monikered Bushrod Whacker (Martin Donovan), fraudulent Irish spiritualists, hapless coppers, and dissolute Irish gentry. It is a Dublin where the spiritualist craze of the late nineteenth century has combined with a native culture around death and grieving. Death photography was a short-lived but very real phenomenon.

Of course, no review written "in these times" is complete without reference to the fact that this darkly comedic drama about the Irish culture of death should air at time when so many of its crucial rituals have been suspended due to the ongoing Covid pandemic, when most of our interpersonal communication is now mediated through moving images by necessity. The desire to hold onto the frozen image of a departed loved one hits much harder in a context where people have been forced to say goodbye by the means of often frozen and stuttering images on mobile phone and tablet screens. In its unintended way it is a timely series.

Sheamus Sweeney is an independent scholar. In 2013 he was awarded his doctorate for a study of David Simon's HBO series The Wire.

sheamus.sweeney@dcu.ie

\section{Rialto (2019)}

Tony Tracy

Interior-day-A middle-aged man in his place of work talks with a work colleague, then answers the phone. Exterior-day-A high angle shot of a modern port, thousands of containers neatly piled high; a car is seen leaving. INT-day - a charmless modern shopping centre. In the public toilets the man nervously engages in a sexual rendezvous with a young streetwise male before anxiously fleeing. EXT-day - the man is seen in the lush garden of his suburban family home where he assumes the familiar role of father and husband.

The opening scenes of Rialto offer a quick series of counterpoints: close ups and wide shots; open and claustrophobic spaces; emotional vulnerability and crude sexuality. They blend private and public, intimacy and anonymity, the tender and transactional. Holding these oppositions together is the figure of Colm (Tom Vaughan Lawlor) who is clearly under a great deal of pressure. Loved by his kind and sympathetic wife (Monica Dolan), Colm is in the midst of some kind of crises and while it evidently has a sexual dimension, a combination of factors combine to suggest something more complex and fundamental. 
As the narrative unfolds, we learn that Colm is coming to terms with the recent death of his (abusive) father and supporting his mother to get rid of his belongings and arrange a memorial service. Then a recent takeover at his work threatens his job. Unable to confide in his wife and alienated from his son he seeks comfort in subsequent encounters with the male prostitute from the opening scene - Jay - that become something deeper.

Rialto resonates on several levels with Adam and Paul (2004) the film that first brought its writer Mark O'Halloran to widespread attention, along with director Lenny Abrahamson. Its feeling for contemporary inner-city masculinities for instance, themes of alcohol and alienation, and its sense of Dublin, including the evocative - and loaded backdrop of the Poolbeg chimneys. Abrahamson and O'Halloran subsequently collaborated on Garage and the RTE mini-series Prosperity, before moving on to a range of other projects individually. (They have recently worked together again on the adaptation of Sally Rooney's Conversations With Friends). While Abrahamson attained an increasingly international reputation through successes with Frank, Room and Normal People, O'Halloran has remained busy and creatively stretched in his dual profession as a writer and actor for film and stage.

While their separate, subsequent work has been varied one can retrospectively identify in Adam and Paul as an early but enduring touchstone for stories that foreground male characters who, for a variety of reasons, struggle to fit in with a variety of social situations and contexts. For Abrahamson, in work as diverse as What Richard Did, The Little Soldier and more recently Normal People, class has largely functioned as the means for exploring such themes while O'Halloran - as actor and writer (and it may be that the former informs the latter) - often focuses on the emotional vulnerability and insecurity of men. In Garage these perspectives combined to produce an unforgettable portrait of rural manhood in which Pat Shortt's Josie became a tragic victim of the Celtic Tiger's avarice (in the form of the Garage owner) but had its roots in a profound loneliness and clumsy longing for connection where he shares porno videos with a young man. Similarly Rialto focuses on another lonely man who uses sex and sexuality as a means of encounter and male companionship.

Rialto began as an in situ drama, commissioned by the acclaimed on theatre company THISISPOPBABY and premiered in an offsite B\&B in Dublin's inner city at the Dublin Theatre Festival in 2011. That performance starred just two actors (to the film) and was confined to the intimate surroundings of a bedroom where the audience stood observing the interplay between Philip Judge (as the older man) and Ciaran McCabe. It subsequently won Irish Times Best New Play and was optioned by producer Alan Maher for Marcy Productions.

To describe Rialto as the screen adaptation of Trade is only partially true. During its extensive development period O'Halloran was bound to "open it up" beyond its tiny original set but in doing do was compelled to extend beyond an intensely intimate encounter played out in real time. In doing so he could bring a greater sense of context to the encounter but also risk losing the intensity (as well as the sense of place) that made it so compelling. That scene is still at the heart of the film - literally so, occurring at midpoint in the narrative - but O'Halloran (and Burns Mackie) set out to imagine what happens before and after it; the events leading to this tawdry setting and the emotional fallout arising from it. But if space is opened out, the emotional intensity remains both focused and sustained through Vaughan Lawlor's performance as Colm who remains the centre of every scene and whose pain and confusion wracks a restless body that constantly inhales cigarettes and cheap beer, submits to illicit and rough sex, is unable to touch his wife, wanders suicidal along the Dublin shoreline, and falls in the door of his home drunk.

If the death of his father and loss of his job are tremors that threaten and undermine the edifice of Colm's middle-aged married manhood, they disturb something deeper and ultimately unresolved in the psycho-sexual substratum; his yearning for homosexual intimacy. As an added scene, when Colm visits Jay in his flat, shows that his yearning is more 
complicated than physical desire. O'Halloran further complicates this in positioning Jay as both father and surrogate son; a boy and man who works in order to take care of his baby daughter but with none of the self-doubt or self-loathing that are eating Colm. However, rather than clarifying matters, this pushes him further into self-disgust and he violently and grotesquely rejects his son in the most emotionally devastating of the film's scenes.

Some years ago, Brian Finnegan spoke eloquently at the IFI's annual Spotlight event of Irish cinema's poor record of LGBTQ portrayals and counted just six gay protagonists in the history of Irish film. Is Rialto a film that remedies this history? And does it matter? On very obvious one level it does and that relates to the scope of representations available within Irish film. One could make the argument that Irish cinema has long been characterized by an over-representation of young men [by young men] and to an extent that continues here. But neither Colm nor Jay could be said to offer anything positive to Finnegan's analysis and Colm's sexuality ultimately remains entirely unresolved and re-suppressed - through a disciplining of the body.

Nonetheless, this is a queer film insofar as it questions ideas of (male) sexuality and ageing. That O'Halloran - a very visible member of the LGBTQ community - should choose to tell so unresolved a story, rather than (say) make a film with gay characters at the centre, is both revealing and mischievously disruptive. On the one hand one might say that it is indicative of post-marriage equality referendum Ireland (2015) where the theme of homosexual relationships is no longer taboo nor marginal in and of itself. But while that event took place after the production of the play, the film asserts an enduring homophobia and surrounding shame amongst an older generation, as well perhaps, as the limits of masculinity in a culture that remains stubbornly heteronormative. Whether or not Colm is a closeted homosexual is left unclear, but there is little doubt that this conventionally married, middleaged and unemployed individual is in deep trouble with little sense of how to forge a path forward as a father, husband or man.

While Rialto shares similarities and can be fruitfully discussed in relation to the considerable number of contemporary Irish films dealing with Irish masculinities in crises Glassland; What Richard Did; Michael Inside; Mammal, to name but a few - it rises above the majority by bringing nuance and a measure of maturity to that familiar theme. A spare but coherent screenplay by O'Halloran (though some might object to its ending), a harrowing performance by Vaughan Lawlor that is both raw and modulated, and lucid direction by Pete Mackie Burns that holds exterior realism and interior turmoil in tension, ground a story that is by turns extreme and every-day. Secondary roles are also crucial to its success, notably Monica Dolan's deeply sympathetic portrayal of Claire and the more callous, but equally credible Tom Glynn-Carney as Jay, who emerges as the most grounded and in control of all the film's characters.

Tony Tracy lectures in film and media studies at Huston School of Film and Digital Media, NUI Galway. His research encompasses contemporary and historical Irish and Irish American themed cinemas with a particular emphasis on constructions of masculinities. With Roddy Flynn is co-author of the Historical Dictionary of Irish Cinema [Rowman and Littlefield, 2019] and Principal Investigator on the GenderNet+ project "MascAge: Images of Ageing Masculinities in Contemporary Film and Literature".

tony.tracy@nuigalway.ie 